\title{
EVALUATION OF RATIONAL PARAMETERS OF COMBINED STAYED ROOF
}

\author{
Olga Blazevica-Juhnevica ${ }^{1}$, Dmitrijs Serdjuks ${ }^{2}$, Raimonds Ozolins ${ }^{3}$, Vadims Goremikins ${ }^{4}$ \\ 1,2,3,4 Institute of Structural Engineering and Reconstruction, Faculty of Civil Engineering, Riga Technical University, \\ Azenes Str. 16/20, LV-1048 Riga, Latvia \\ E-mail:1'okta@inbox.lv(correspondingauthor); ${ }^{2}$ dmitrijs.serdjuks@rtu.lv; ${ }^{3}$ raimonds.ozolinsh@apollo.lv; \\ ${ }^{4}$ goremikins@gmail.com
}

\begin{abstract}
Combined stayed roof with the span equal to $60 \mathrm{~m}$ is considered in the paper. The framework of the roof is formed by two groups of structural members, which are placed in longitudinal and transversal directions. The main girder and pylons, which form the main frame, just as suspenders are the members, placed in the longitudinal direction. Transversal frames, which are formed by the trusses and columns, are the members, placed in transversal direction. Structural steel S355 is considered as a materials of all rigid members - pylons, columns and girders. Three variants of materials for suspenders were considered. Steel cables with modulus of elasticity of $1.70 \cdot 10^{5} \mathrm{MPa}$ and tensile strength of steel wire of $1960 \mathrm{MPa}$ were the first variant. Carbon fiber reinforced plastic (CFRP) with the modulus of elasticity of $1.65 \cdot 105 \mathrm{MPa}$, tensile strength of $2800 \mathrm{MPa}$ and ultimate strain in tension of $1.8 \%$ was the second variant. Hybrid composite element, consisting from steel, CFRP and Kevlar components with the volume fractions of 0.6, 0.2 and 0.2, correspondingly, was the last variant of suspenders. The dependences of material consumption and main geometrical parameters of combined stayed roof were obtained for three above mentioned variants of suspender materials. They were obtained on the basis of numerical experiment, which was carried out using the software LYRA 9.4. It was stated that the rational values of the number of suspenders, transversal frame bay and height of pylon are equal to $8,6 \mathrm{~m}$ and $18 \mathrm{~m}$, correspondingly.
\end{abstract}

Keywords: suspender, hybrid composite element, cable roof, load-bearing

\section{Introduction}

Large span structures are widely used for such types of residential and industrial buildings as exhibition and trade halls such as supermarkets, airports, stations and hangar roofing, etc. Possibility to use internal space rationally due to the decreased number of intermediate supports, expressiveness of architectural shapes decreased in comparison with the short span structures, and materials expenditure are some of the main reasons, why large span structures cause interest of engineers and architects. The investigation, which is carried out in this study, is connected with the choice of proper structural solutions for a large span exhibition hall and evaluation of its rational parameters. The main objective of this study is to choose the substantiated structural solution for the exhibition hall with the span equal to $60 \mathrm{~m}$. The choice of structural materials and main geometrical parameters of the considered structure must also be substantiated.

\section{Choice of structural solution}

Large span structures can be divided into several groups depending on the type of the used load bearing members.

The first group includes large span structures mainly consisting from the compliant members. Pneumatic domes and shells, cable roofs are some of the examples of such large span structures (Goremikins 2013, Ermolov 1980, Kirsanov 1981). Load bearing members, which can take up longitudinal tension forces only, are mentioned here as the compliant members. The flexural rigidity of such members is marginal and can be neglected during the analyses. Steel, composite and hybrid composite cables are the examples of such compliant members. Decreased material consumption and increased compliance are the main characteristics of this group of large span structures.

The second group includes large span structures consisting from the rigid members, such as beams, trusses, and columns, slabs, etc., which can take up bending moment and compression force. Beam, truss and arch system large span roofs, such as domes and shells, are some examples of such large span structures. Decreased compliance and increased material consumption are the main characteristics of this group of large span structures.

The third group includes large span structures consisting from the rigid members and compliant ones. The main purpose of adding compliant members is improvement of structural schemes of rigid members and taking up of design loads, acting on the structure. Combined cable roofs are the main examples of such group of large span structures (Goremikins et al. 2012 a, Mihailov 2002). Combined cable roofs are characterized by the decreased, in comparison with the cable roofs, compliance and decreased, in comparison with the beams, truss and arch systems large span roofs, material consumption. Thus, combined structures took an intermediate position between the first and second groups of large span structures mentioned above. So, a combined structure will be considered.

Combined structures also can be divided into several groups depending on their structure. But the combined stayed roofs take a special position among the combined structures due to their decreased compliance and possibility to provide stability of shape (Goremikins et al. 2012 b, Kikot 2013). In this connection, a combined stayed roof is considered as a structural scheme for the exhibition hall with the span equal to $60 \mathrm{~m}$., which is considered as an object of investigation (Fig. 1). 


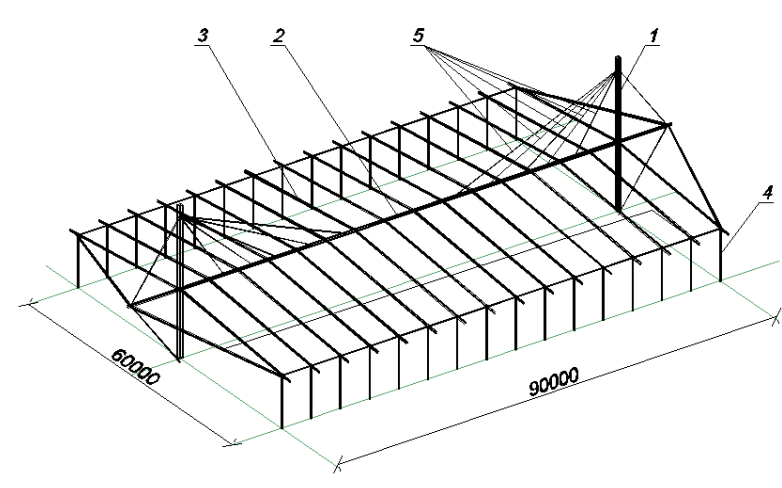

Fig.1. Scheme of the combined stayed roof: 1 - pylon; 2 -main girder; 3 - girder of transversal frame; 4 - column of transversal frame; 5 - suspenders.
The combined stayed roof of the sport hall, which was erected in Brunswig, German (Kirsanov 1981), was considered as a prototype for the roof of the exhibition hall, which was considered as an object of investigation.

Pylons, main girder and suspenders are the main load bearing members placed in the longitudinal direction. The main girder is placed horizontally without two slopes in contrast to the considered prototype (Fig.2.)

Transversal frames with the pinned girder to column connections and restrained in foundation columns are the main load bearing members placed in the transversal direction. The girders are two slope trusses with parallel chords and triangular web (Fig.2.).

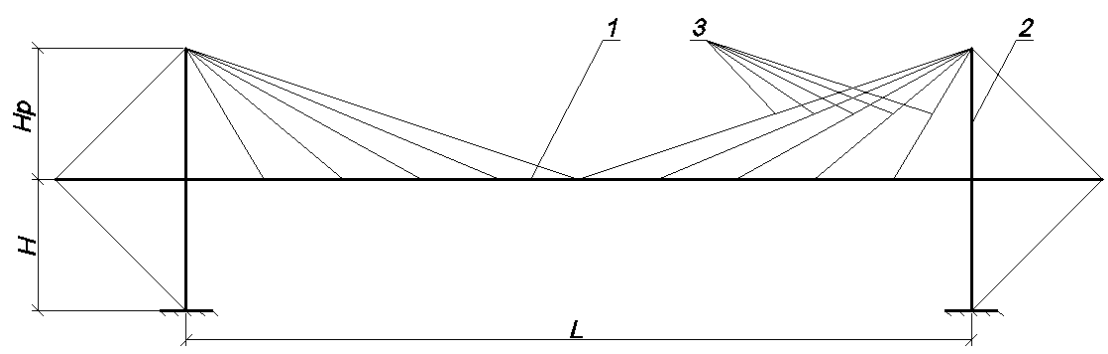

a)

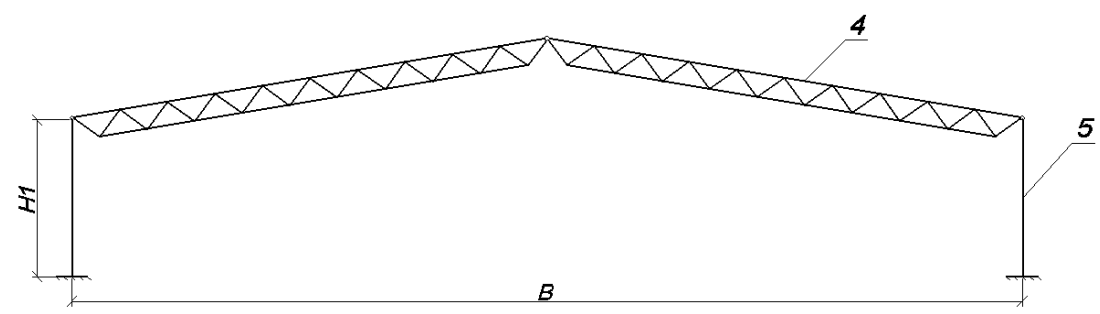

b)

Fig.2. Cross-section of combined stayed roof: $a$ ) - in longitudinal direction; $b$ ) - in transversal direction : 1 - main girder; 2 - pylon; 3 - suspenders; 4 - girder of transversal frame; 5 - column of transversal frame; $L$ - span of the main girder; $H$ - height of bottom part of pylon; $H_{p}$ - height of top part of pylon ; $H_{l}$ - height of column of transversal frame.

\section{Choice of structural materials}

Steel of grade S355 was chosen as a structural material for the main girder, pylons, girders of transversal frames and columns. Application of the increased grade of steel is based on the requirement to use structural material with the increased specific strength. Using steel grade S355 allows decreasing materials expenditure on the one hand and not using the steel of higher grade S460, on the other. Yielding and tensile strength such as modulus of elasticity for steel of grade $\mathrm{S} 355$ are equal to 355,510 and $2.10 \cdot 10^{5} \mathrm{MPa}$, respectively.

Three variants of materials for suspenders were considered. Steel cables with modulus of elasticity of $1.70 \cdot 10^{5} \mathrm{MPa}$ and tensile strength of steel wire of 1960 MP was the first variant. Carbon fiber reinforced plastic (CFRP) with the modulus of elasticity of $1.65 \cdot 10^{5} \mathrm{MPa}$, tensile strength of $2800 \mathrm{MPa}$ and ultimate strain in tension of $1.8 \%$ was the second variant. Hybrid composite element, consisting from steel, CFRP and Kevlar components with the volume fractions of $0.6,0.2$ and 0.2 , correspondingly, was the last variant of suspenders (Serdjuks et al. 2008a). The modulus of elasticity and tensile strength of hybrid composite element were evaluated as $1.14 \cdot 10^{5} \mathrm{MPa}$ and $2152 \mathrm{MPa}$, correspondingly. Approach for evaluation of the mechanical properties of the tensioned hybrid composite element (Serdjuks et al. 2008b, Goremikins et al. 2012d), which is based on the method of proportional summing, was used.

Generally known dependence was used for the engineering evaluation of the modulus of elasticity of the hybrid composite cable. The dependences are given for the hybrid composite cable on the basis of steel, CFRP and Kevlar.

$E=\Psi_{C} E_{C}+\left(1-\Psi_{C}-\Psi_{S}\right) E_{K}+\Psi_{S} E_{S}$, 
where

$$
\psi_{C}=\frac{A_{C}}{A}, \psi_{S}=\frac{A_{S}}{A},
$$

$E_{S}=\frac{\sum_{i=1}^{n} m_{i} A_{i} E_{i} \sin \left(90-\alpha_{i}\right)\left[1-(1+v) p_{i} \cos ^{2} \alpha_{i}\right]}{A_{S}}$

$A_{i}=\pi r_{0}^{2}$

$p_{i}=\left(1-\mu \frac{R_{i}}{r_{i}} \cos ^{2}\left(90-\alpha_{i}\right)\right) \times$

$\left[1-\frac{R_{i}^{2}}{4 r_{i}^{2}}\left(1-\frac{\mu}{1+\mu} \cos ^{2}\left(90-\alpha_{i}\right)\right) \cos ^{2}\left(90-\alpha_{i}\right)\right]$,

where: $E=$ modulus of elasticity of hybrid composite cable; $A=$ cross-sectional area of hybrid composite cable; $A_{C}, A_{S}=$ cross-sectional areas of CFRP and steel components, respectively; $E_{C}, E_{K}, E_{S}=$ moduli of elasticity of CFRP, Kevlar and steel components, respectively; $m_{i}=$ amount of steel wires in the i-th strand; $A_{i}=$ cross-sectional area of the separate steel wire in the ith strand; $r_{0}=$ radius of separate steel wire; $E_{i}=$ modulus of elasticity of steel wire; $\alpha_{i}$ - angle of i-th steel wire strands twisting; $\mu=$ Poison's ratio of steel wire; $R_{i}=$ radius of $\mathrm{i}$-th steel wire strand; $r_{i}=$ distance between the centres of $\mathrm{i}$-th steel wire strand and cable.

Approach to the evaluation of the mechanical properties of the tensioned hybrid composite element was tested experimentally. Three specimens, consisting from four steel and one CFRP bands were tested. CFRP band Sika CarboDur S-512 and cold rolled steel of grade DC01 (EN 10130-06) were used. All bands were joined together by the epoxy glue Sika Dur-30 and have cross-sections 50X1.2 mm. Breaking forces and load-strain curves were obtained as a result of experiment. Difference between the analytical and experimental results does not exceed $20 \%$. It enables to consider the adopted approach as valid.

\section{Method of analysis}

Evaluation of the main geometrical parameters of the combined stayed roof was set as one of the main tasks of this paper. The angle of transversal frames girder inclination $(\alpha)$, number of suspenders $(n)$, transversal frames bay $(b)$ and height of top part of pylon $\left(H_{p}\right)$ are considered as the main geometrical parameters of the combined stayed roof (Fig.3.).

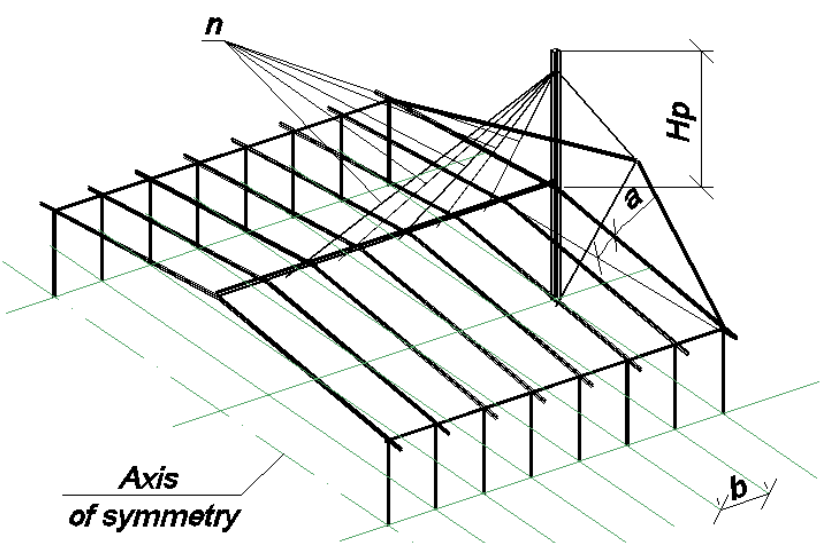

Fig.3. Main geometrical parameters of the combined stayed roof: angle of transversal frames girder inclination $(\alpha)$, number of suspenders (n), transversal frames bay $(b)$ and height of top part of pylon $\left(H_{p}\right)$

The dependences of material consumption and the main geometrical parameters of the combined stayed roof were obtained for three above-mentioned variants of suspender materials. Each from the mentioned above main geometrical parameters has three values (maximum, minimum and mean). It means that the total number of treated variants was equal to 81 for each of the three above-mentioned variants of suspender materials.

The dependences were obtained as a second power polynomial equation on the basis of numerical experiment, which was carried out using the software LYRA 9.4.

$$
\begin{aligned}
& G=b_{0}+b_{1} \cdot \alpha+b_{2} \cdot n+b_{3} \cdot b+ \\
& +b_{4} \cdot H_{p}+b_{12} \cdot \alpha \cdot n+b_{13} \cdot \alpha \cdot b+b_{14} \cdot \alpha \cdot H_{p}+ \\
& +b_{23} \cdot n \cdot b+b_{24} \cdot n \cdot H_{p}+b_{34} \cdot b \cdot H_{p}+b_{11} \cdot \alpha^{2}+ \\
& +b_{22} \cdot n^{2}+b_{33} \cdot b^{2}+b_{44} \cdot H_{p}^{2},
\end{aligned}
$$

A spacious model of the combined stayed roofs framework was analyzed to consider the action of design load combination, which involves dead weight, snow and wind. The snow load uniformly distributed by the surface of the roof was considered. Internal forces acting in the load-bearing members then were used for determination of cross-sections parameters (Kirsanov 2011). Dimensioning of the members cross-sections was carried out using the Eurocode 3. Design schemes of transversal frame and main girder are shown in Figure 4. Deformations of pylon and corresponding displacements of supporting points of main girder were neglected.

The main girder has a welded double-T cross-section with two webs. Column of transversal frame has hotrolled double-T cross-section (EN 10025). The girders of transversal frames are two slope trusses with parallel chords and triangular web with hollow rectangular crosssections (EN 10219). 
a)

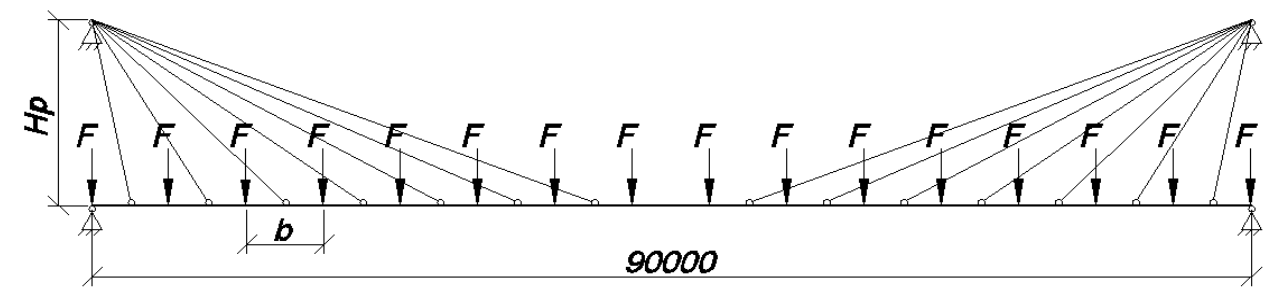

b)

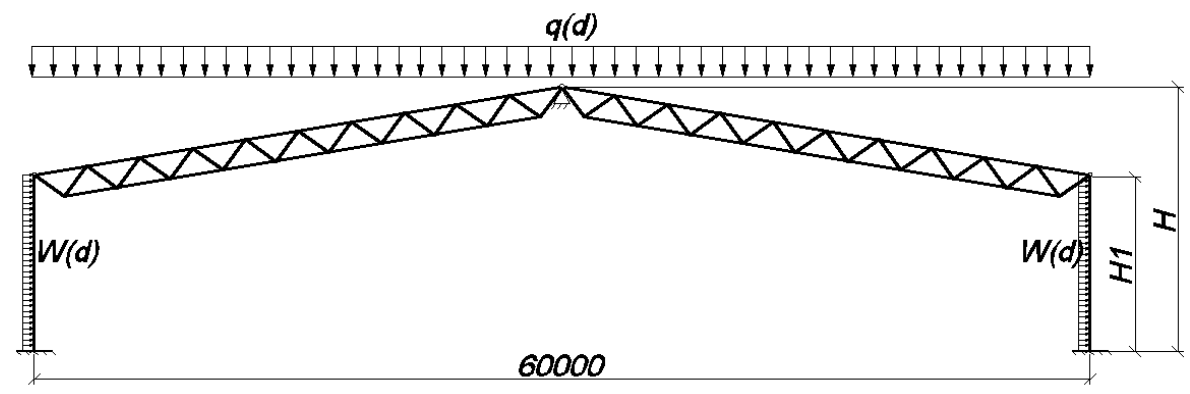

Fig.4. Design schemes of the main girder $a$ ) and transversal frame; $b) P$ - concentrated forces, acting on the main girder from the transversal frame; $F_{d}$ - vertical load, acting on the transversal frame. It includes dead weight of the roof and snow load; $W(d)$ - horizontal wind load.

The coefficients of dependences of material consumption and main geometrical parameters of the combined stayed roof were obtained by the less squares method.

Rational from the point of view of material consumption values of transversal frames girder inclination $(\alpha)$, suspenders amount $(\mathrm{n})$, transversal frames bay $(B)$ and height of top part of pylon $\left(H_{p}\right)$ were determined by the system of equations (7).

$$
\left\{\begin{array}{l}
\frac{\partial G}{\partial \alpha}=b_{1}+b_{12} \cdot \mathrm{n}+b_{13} \cdot \mathrm{b}+\mathrm{b}_{14} \cdot H_{p}+2 \cdot \mathrm{b}_{11} \cdot \alpha=0, \\
\frac{\partial G}{\partial n}=b_{2}+b_{12} \cdot \alpha+b_{23} \cdot b+b_{24} \cdot H_{p}+2 \cdot b_{22} \cdot n=0, \\
\frac{\partial G}{\partial b}=b_{3}+b_{13} \cdot \alpha+b_{23} \cdot n+b_{34} \cdot H_{p}+2 \cdot b_{33} \cdot b=0, \\
\frac{\partial G}{\partial H_{p}}=b_{4}+b_{14} \cdot \alpha+b_{24} \cdot n+b_{34} \cdot b+2 \cdot b_{44} \cdot H_{p}=0 .
\end{array}\right.
$$

The obtained results then were corrected by the inspection.

\section{Evaluation of the rational parameters of the combined stayed roof}

The angle of transversal frames girders inclination changes within the limits from $9^{\circ}$ to $18^{\circ}$. Number of suspenders, transversal frames bay and height of pylon change within the limits from 4 till 8 , from $4.5 \mathrm{~m}$ till $7.5 \mathrm{~m}$ and from $12 \mathrm{~m}$ till $18 \mathrm{~m}$, respectively.

Snow and wind loads were determined for Riga climatical conditions (Semenov 2012). Maximum intensities of dead weight, snow and wind loads are equal to $1.252, \quad 1.500$ and $0.315 \mathrm{kPa}$, correspondingly.
The roofing consists from the profiled steel sheets, heat insulation and protective layers.

The dependences of material consumption and angle of transversal frames girder inclination $(\alpha)$, number of suspenders $(n)$, transversal frames bay $(b)$ and height of top part of pylon $\left(H_{p}\right)$ were obtained for cases, when suspenders were made from steel, CFRP and hybrid composite on the basis of steel, CFRP and Kevlar. The material consumption was obtained as a total dead weight of suspenders, main girders and transversal frames. Dead weight of pylons was not taken into account.

The dependence, which was obtained for steel suspenders, is shown in Figure 5.

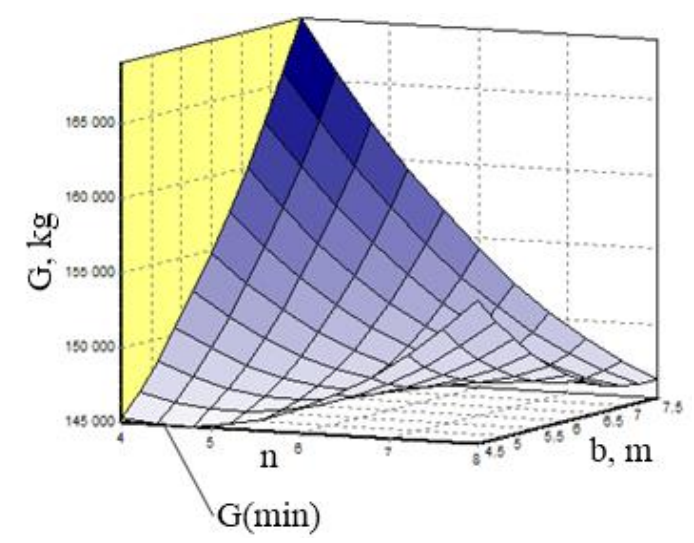

Fig.5. Total material consumption as a function of the number of suspenders and bay of transversal frames for variant with the steel suspenders. The angle of transversal frames girder inclination and height of top part of pylon are constant and equal to $1.50^{\circ}$ and $21.87 . \mathrm{m}$, correspondingly.

The dependence, which was obtained for CFRP suspenders, is shown in Figure 6. 


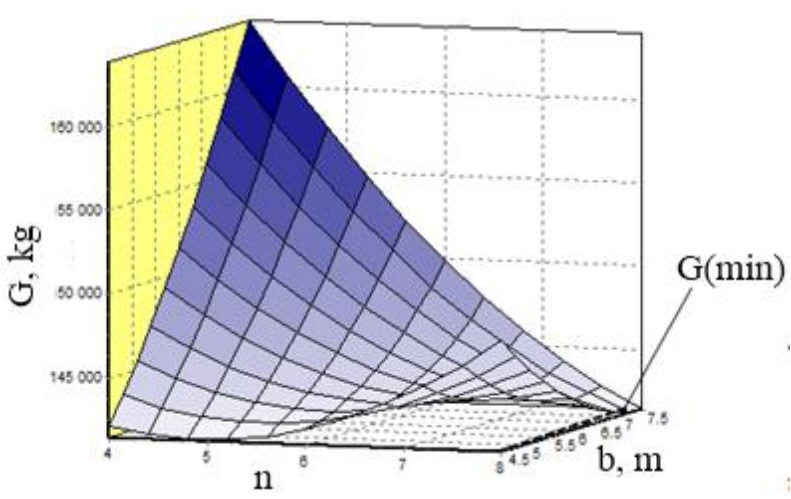

Fig.6. Total material consumption as a function of the number of suspenders and bay of transversal frames for variant with the CFRP suspenders. The angle of transversal frames girder inclination and height of top part of pylon are constant and equal to $4.08^{\circ}$ and $21.76 \mathrm{~m}$, correspondingly.

The dependence, which was obtained for hybrid composite suspenders, is shown in Figure 7.

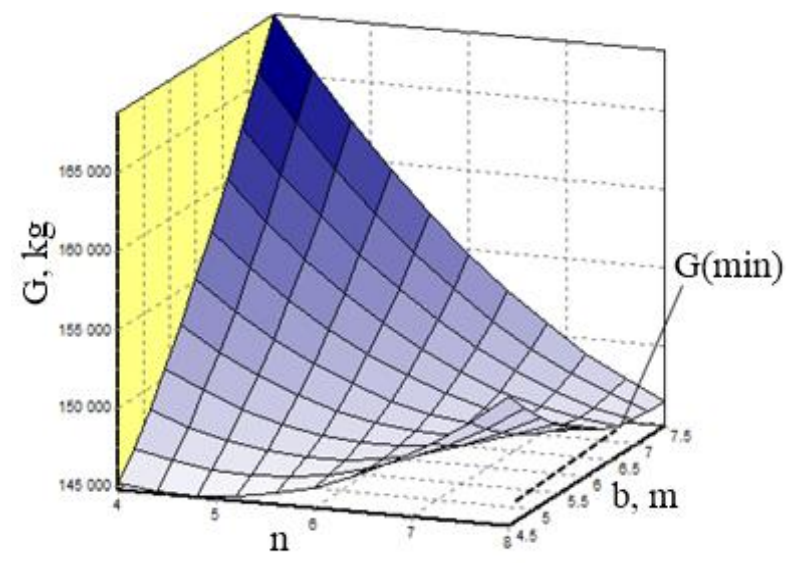

Fig.7. Total material consumption as a function of the number of suspenders and bay of transversal frames for variant with the hybrid composite suspenders. The angle of transversal frames girder inclination and height of top part of pylon are constant and equal to $4.79^{\circ}$ and $29.59 \mathrm{~m}$, correspondingly.

The dependences presented in Fig.5-7 have similar characteristics. Total material consumption for all three variants of suspender materials practically changes within the limits from 79.59 to 173.23 tons. The maximum difference of total minimum material consumption was equal to $5.00 \%$ and took place between the variants with steel and CFRP suspenders.

The coefficients of second power polynomial equations for the variants of structure with steel, hybrid composite and CFRP suspenders are given in Table 1.
Table 1. Coefficients of second power polynomial equations for the variants of structure with steel, hybrid composite and CFRP suspenders

\begin{tabular}{|l|l|l|l|}
\hline $\begin{array}{l}\text { Coefficients } \\
\text { of second } \\
\text { power } \\
\text { polynomial } \\
\text { equations }\end{array}$ & $\begin{array}{l}\text { Variant with } \\
\text { steel } \\
\text { suspenders }\end{array}$ & $\begin{array}{l}\text { Variant with } \\
\text { hybrid } \\
\text { composite } \\
\text { suspenders }\end{array}$ & $\begin{array}{l}\text { Variant with } \\
\text { composite } \\
\text { suspenders }\end{array}$ \\
\hline$b_{0}$ & 68699.10 & 62170.00 & 60417.00 \\
\hline$b_{1}$ & 9931.65 & 9597.84 & 9451.50 \\
\hline$b_{2}$ & 4167.54 & 4057.64 & 3369.88 \\
\hline$b_{3}$ & 14886.00 & 16884.20 & 17479.80 \\
\hline$b_{4}$ & -1507.24 & -1065.75 & -1119.34 \\
\hline$b_{11}$ & -384.05 & -395.67 & -383.25 \\
\hline$b_{12}$ & 24.51 & 53.15 & 56.24 \\
\hline$b_{13}$ & -998.03 & -965.47 & -973.56 \\
\hline$b_{14}$ & 6.46 & 19.83 & 7.35 \\
\hline$b_{22}$ & 832.69 & 743.39 & 689.89 \\
\hline$b_{23}$ & -2678.71 & -2521.56 & -2376.25 \\
\hline$b_{24}$ & 0.70 & -10.86 & 4.27 \\
\hline$b_{33}$ & 1061.04 & 860.37 & 670.63 \\
\hline$b_{34}$ & 1.33 & -45.62 & 0.69 \\
\hline$b_{44}$ & 33.76 & 23.30 & 23.96 \\
\hline
\end{tabular}

The values of the obtained coefficients allow analyzing the level of importance of each out of four abovementioned main geometrical parameters of the combined stayed roof. The bay of transversal frames and the number of suspenders are the parameters which most significantly influence the total material consumption.

Rational from the point of view of total material consumption values of transversal frames girder inclination angle, number of suspenders, transversal frames bay and height of top part of pylon were determined (see Table 2). The results were completed by the additional dependences, which were obtained separately for the main girder and suspenders.

Table 2. Rational values of transversal frames girder inclination, number of suspenders, transversal frames bay and height of top part of pylon *

\begin{tabular}{|l|l|l|l|}
\hline $\begin{array}{l}\text { Main } \\
\text { geometrical } \\
\text { parameters of } \\
\text { the combined } \\
\text { stayed roof }\end{array}$ & $\begin{array}{l}\text { Variant } \\
\text { with steel } \\
\text { suspenders }\end{array}$ & $\begin{array}{l}\text { Variant } \\
\text { with } \\
\text { hybrid } \\
\text { composite } \\
\text { suspenders }\end{array}$ & $\begin{array}{l}\text { Variant } \\
\text { with } \\
\text { composite } \\
\text { suspenders }\end{array}$ \\
\hline $\begin{array}{l}\text { Angle of } \\
\text { transversal } \\
\text { frames girder } \\
\text { inclination } \\
\alpha^{\circ}\end{array}$ & $\underline{9}$ & $\frac{9}{14}$ & $\frac{9}{14}$ \\
\hline $\begin{array}{l}\text { Suspenders } \\
\text { amount } \mathrm{n}\end{array}$ & $\underline{8}$ & $\underline{8}$ & $\underline{8}$ \\
\hline $\begin{array}{l}\text { Transversal } \\
\text { frames bay b, } \mathrm{m}\end{array}$ & $\underline{7.5}$ & $\underline{7.5}$ & $\underline{6.5}$ \\
\hline $\begin{array}{l}\text { Height of top } \\
\text { part of pylon } \\
\text { Hp, m }\end{array}$ & $\underline{18}$ & $\underline{18}$ & $\underline{18}$ \\
\hline
\end{tabular}

* The values in denominator are obtained on the basis of dependences obtained for the main girder only.

So, the combined stayed roof with the angle of transversal frames girder inclination, number of 
suspenders, transversal frames bay and height of top part of pylon equal to $9^{\circ}, 8,6 \mathrm{~m}$ and $18 \mathrm{~m}$, respectively, was considered as a rational solution. Corresponding total material consumptions were equal to $84.00,83.18$ and 79.59 tons for the variants with steel, hybrid composite and CFRP suspenders, respectively. Material consumptions of main girder, girders of transversal frames, columns of transversal frames and suspenders were equal to $15,52,35$ and $4 \%$, correspondingly. So, using CFRP suspenders instead of steel allows decreasing the total material consumption by $5 \%$ only. Cable material consumption decreases 7.57 times, correspondingly. We can also conclude that the type of suspender structural material does not have a big influence on the total material consumption.

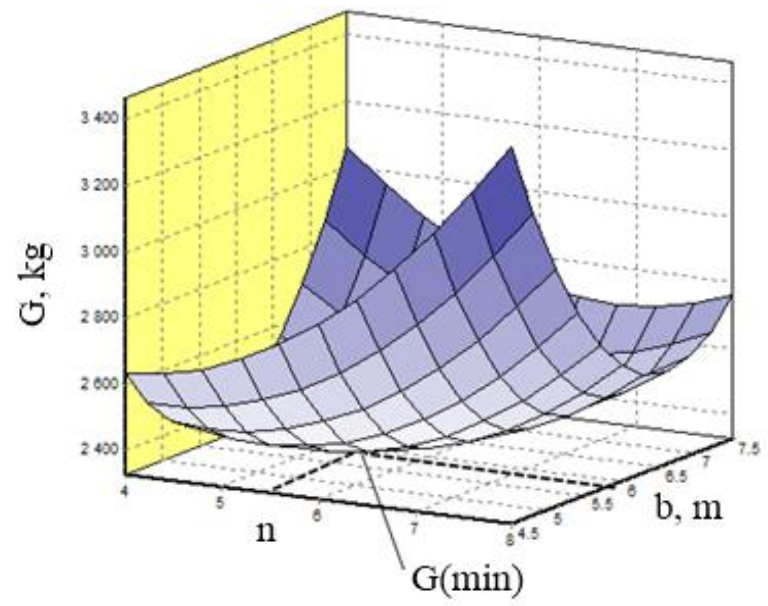

Fig.8. Suspender material consumption as a function of the number of suspenders and bay of transversal frames for variant with the hybrid composite suspenders. The angle of transversal frames girder inclination and height of top part of pylon are constant and equal to 7.01 and $19.61 \mathrm{~m}$, correspondingly.

The dependences of suspender material consumption on the angle of transversal frames girder inclination, number of suspenders, transversal frames bay and height of top part of pylon, were obtained for three variants of suspender materials. The obtained dependences have similar character and can be illustrated by the dependence, which is shown in Fig. 8.

\section{Conclusions}

The combined stayed roof was considered as a preferable structural solution for the exhibition hall with the span equal to $60 \mathrm{~m}$.

It was stated that the angle of transversal frames girder inclination, number of suspenders, transversal frames bay and height of top part of pylon rational from the point of view of material consumption are equal to $9,8,6 \mathrm{~m}$ and $18 \mathrm{~m}$, respectively. Corresponding total material consumptions were equal to $84.00,83.18$ and 79.59 tons for the variants with steel, hybrid composite and CFRP suspenders, respectively.
It was shown that using of CFRP suspenders instead of steel allows decreasing the total material consumption by $5 \%$ only. Cable material consumption decreases 7.57 times, correspondingly.

\section{References}

Ermolov, V., 1980. Pnevmaticeskije zdanija $i$ konstrukciji. Moskva: Strijizdat, 304.p.

Goremikins, V., 2013. Rational Large Span Prestressed Cable Structure. Doctoral Thesis. Riga: RTU, 155. p.

Goremikins, V.; Rocens, K.; Serdjuks, D., 2012a. Decreasing Displacements of Prestressed Suspension Bridge. Journal of Civil Engineering and Management, 18(6), pp. 858-866. Available at: http://dx.doi.org/10.3846/13923730.2012.720936

Goremikins, V.; Rocens, K.; Serdjuks, D., 2012b. Decreasing of Displacements of Prestressed Cable Truss. World Academy of Science, Engineering and Technology, 63, pp. 554-562.

Goremikins, V.; Rocens, K.; Serdjuks, D. 2012c. Cable Truss Analyses for Suspension Bridge. In Proc. of 10th International Scientific Conference "Engineering for Rural Development”, 24-25 May, 2012, Jelgava, Latvia, 11, pp. 228-233.

Goremikins, V.; Rocens, K.; Serdjuks, D., 2012d. Analysis of Hybrid Composite Cable for Prestressed Suspension Bridge. In Proc. of the 17th International Conference ,Mechanics of Composite Materials”, 28 May-1 June, 2012, Riga, Latvia, pp. 93.

Kikot, A. A.; Grigoriev, V. V., 2013. Influence of flange width and wall parameters on effectiveness of cold-formed steel Sigma-profile in bending behavior. Magazine of Civil Engineering, 36, pp. 97-102. http://dx.doi.org/10.5862/MCE.36.12

Kirsanov, M. N., 2011. Static calculation and analysis of spatial rod system. Magazine of Civil Engineering, 6, 28-34. p.

Kirsanov, N., 1981. Visjačie $i$ vantovie konstrukciji Moskva: Strojizdat. pp. 158.

Mihailov, V., 2002. Predvariteljno naprjažennije kombinirovannije $i$ vantovije konstrukciji. Moskva: ACB, 255.p.

Pakrastinsh, L.; Rocens, K.; Serdjuks, D., 2006. Deformability of Hierarchic Cable Roof. Journal of Constructional Steel Research, 62, pp. 1295-1301.

http://dx.doi.org/10.1016/j.jcsr.2006.04.025

Semenov, A. A.; Porivaev, I. A.; Safiullin, M. N., 2012. Research of wind and snow cover loads on the roofs of the vertical cylindrical tanks. Magazine of Civil Engineering, 5(31), pp. 12-22. http://dx.doi.org/10.5862/MCE.31.2

Serdjuks, D.; Rocens, K., 2004. Decrease the Displacements of a Composite Saddle-Shaped Cable Roof. Mechanics of Composite Materials, 40(5), pp. 675-684. Available at: http://dx.doi.org/10.1023/B:MOCM.0000047234.72813.2e

Serdjuks, D.; Rocens, K., 2008a. Hybrid Composite Cable with Steel Component as a Structural Element. An International Journal Advanced Steel Construction, 4(3), pp. 184-197.

Serdjuks, D.; Rocens, K.; Pakrastins, L., 2008b. Hybrid Composite Cable with an Increased Specific Strength for Tensioned Structures. The Baltic Journal of Road and Bridge Engineering, 3(3), pp. 129-136. Available at: http://dx.doi.org/10.3846/1822-427X.2008.3.129-136 